\title{
Are apprenticeships business cycle proof?
}

\author{
Samuel Lüthi ${ }^{1 *}$ (1) and Stefan C. Wolter ${ }^{2}$
}

\begin{abstract}
Although there is evidence that apprenticeship training can ease the transition of youth into the labour market and thereby alleviate youth unemployment, many policymakers fear that firms will reduce the number of apprenticeship positions during economic crises, thus exacerbating the problem of youth unemployment. Using recent panel data of Swiss cantons and dynamic regression models, we examine the relationship between newly created apprenticeships and the business cycle. The empirical results suggest that economic shocks induce a pro-cyclical, moderate response in the apprenticeship market, both immediately and in subsequent years.
\end{abstract}

Keywords: Apprenticeship training, VET, Education, Business cycle, Error correction model

\section{Introduction}

In the aftermath of the 2008 financial and economic crisis, many governments and international agencies have been advocating for apprenticeship training, which could be a promising answer to soaring youth unemployment (cf. Heyes, 2013; OECD, 2010; Quintini \& Manfredi, 2009; Steedman, 2014). Some even argue that, during a recession, apprenticeships 'could pay a "double dividend": securing the transition towards employment and lowering labour costs' (Scarpetta, Manfredi, \& Sonnet, 2010, p.4). However, as a market-driven type of education, apprenticeships are not uncontroversial in the context of economic crises. Since firms are free to decide whether to train or not, policymakers fear that many firms, while struggling to survive in times of recessions, might either cut training expenditures or even close businesses. As a consequence, the number of apprenticeships might respond to business cycles in a pro-cyclical fashion (Brunello, 2009). While general education provided by schools does not react to economic cycles (Muehlemann, Wolter, \& Wueest, 2009), a large proportion of apprenticeship training in the educational system might therefore

\footnotetext{
${ }^{*}$ Correspondence: smltbslth@gmail.com

This research was co-funded by the Leading House on the Economics of Education, a research initiative of the Swiss State Secretariat for Education, Research and Innovation.

${ }^{1}$ Centre for Research in Economics of Education, University of Bern, Bern, Switzerland

Full list of author information is available at the end of the article
}

rather aggravate than alleviate an economic crisis for youth.

The objective of this paper is to empirically examine the relationship between the number of apprenticeships and the business cycle. For this purpose, we use panel data from Swiss cantons between 1987 and 2016 to regress the number of new apprenticeships on economic changes (i.e. the GDP growth rate and the unemployment rate) as well as demographic trends (the population aged 16). We extend the time frame of an earlier study by Muehlemann et al. (2009) by 13 years to the period 1987-2016 $(T=30)$ and thereby include the most recent economic fluctuations. Following the 'Great Recession' of 2008/2009, the Swiss economy, which heavily relies on exports, was affected by several negative effects simultaneously: the worldwide recession, the European debt crisis and the overvaluation of the Swiss Franc-all effects potentially reducing the incentive of firms to invest in training and provide apprenticeships.

Figure 1 shows the development of the number of apprenticeships, the population aged 16 and the business cycle in Switzerland. Indeed, during most of the (highlighted) recession periods, the number of apprenticeships decreased, suggesting that the business cycle might affect the number of new apprenticeships. Then again, during the severe crisis in 2008, the number of school graduates (typically aged 16) decreased as well. In turn, fewer students were seeking apprenticeship positions. These dynamics thus raise the question of whether the business 


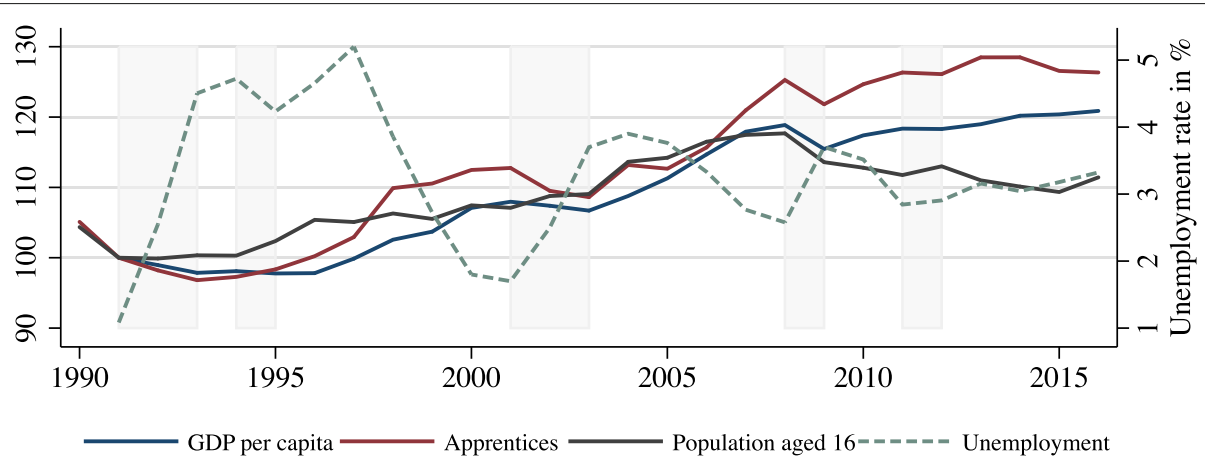

Fig. 1 Time series of apprenticeships, the population aged 16, real GDP per capita (all normalised, $1991=100$ ) and unemployment (rhs)

cycle affects the number of apprenticeships and which factors-economic or demographic-mainly explain the fluctuations.

Our contribution to the existing literature is as follows. We are the first in this context to estimate the dynamic models and thereby allow for short- and longterm effects. While apprentices usually start in autumn (after compulsory school finishes), the recruitment by firms takes place earlier and throughout the year. Therefore, the economic situation during both the same and previous year might affect the firm's hiring decisions, and the timing of a potential response to economic cycles is unclear. Furthermore, in case of economic uncertainty, firms might only postpone initial training plans rather than cut expenditures permanently. The mere looking at immediate reactions would therefore not capture such a behaviour. As a consequence, static models, as found in previous literature, might only reflect part of the firm's response.

Moreover, we analyse whether the behaviour of firms differs during booming periods and recessions. For several reasons, larger firms usually prefer having apprentices simultaneously at different stages of their training period (3 to 4 years). If the economy is growing, such firms thus tend to hire a stable number of apprentices every year, independently of the growth rates, unless the firms expect an exceptional increase in employment. In contrast, if an unexpected recession forces firms to cut expenses or reduce over-capacities and deviate from the business-asusual strategy regarding training efforts, the same firms may temporarily stop hiring new apprentices. Hence, the number of apprenticeships might respond stronger to business cycles during recessions than in periods of economic growth.

Our results show that apprenticeship numbers do respond to business cycles. In the short run, a $1 \%$ point increase of unemployment relates to roughly $1.5 \%$ less apprenticeships, while there is no immediate effect of the GDP growth rate observable. The response to previous year's GDP growth, however, appears pro-cyclical, but the statistical significance is not clear. In the subsequent period, the effect of a changing unemployment rate reverses, suggesting that a number of firms only postpone (or advance) their recruitment, but do not change the number of apprenticeships over a longer time horizon. At the same time, the effect of GDP growth rate changes increases during subsequent years. Overall, we observe both, the demographic changes as well as the economic fluctuations, to have a significant long-term effect on apprenticeship numbers. The magnitude of both effects, however, is moderate, as the vast majority of filled apprenticeship positions are affected by neither economic nor demographic changes.

\subsection{Previous literature}

Although there is abundant literature on training decisions of firms (see Wolter \& Ryan, 2011, with a particular focus on apprenticeship training), the number of studies analysing these decisions in the context of economic fluctuations is rather small. On the theoretical side, there are essentially two training motivations (which could be affected by business cycles) discussed in the literature: the investment- and production-oriented approach (Brunello, 2009; Lindley, 1975; Merrilees, 1983; Wolter \& Ryan, 2011). The former, based on the human capital theory formalised by Becker (1962), sees apprentices as investment, where training costs are mainly motivated through future production gains. Hence, the training strategy depends on expectations regarding future production, and a structural output shock might alter the firm's demand for labour, including apprentices. However, since apprenticeships last between 2 and 4 years, temporary business cycles are less likely to affect the long-term expectations and thus the demand for apprentices.

Firms following a production-oriented training strategy, on the other hand, do not hire apprentices due 
to future expectation but as substitutes for unskilled or skilled workers for the current production. Training costs are thereby compensated by productive work for a comparatively low salary, and for certain apprenticeships, the benefits exceed costs (Muehlemann \& Wolter, 2014). Contrary to the investment approach, the productionoriented theory can thus explain why apprentices are hired even if they leave the firm directly upon completing the training, what is usually the case in Switzerland. Economic downturns, however, decrease the current workload and therefore might affect the immediate demand for apprentices. In addition, rising unemployment rates decrease hiring costs of skilled workers (Muehlemann \& Strupler Leiser, 2018), and hence, a loosening labour market might make hiring skilled workers comparatively more attractive than offering apprenticeships. If unemployment is low, in contrast, it is more difficult to hire skilled workers, and firms turn to hiring more apprentices (Askilden \& Nilsen, 2005).

Based on such theoretical considerations, it might be that firms react differently to changes in GDP and unemployment rates. Dynamic models including the GDP appear to be a promising way to capture the firm's expectations of both, the current but also the future development of their workload, whereas the unemployment rate might reflect hiring costs on the external labour market. Therefore, we include both measures individually and simultaneously, what seems feasible considering that the two indicators for a business cycle are only loosely correlated.

Besides discussing theoretical models, Brunello (2009) also provides a review of the empirical literature on the topic. The general finding is that the number of apprentices responds in a pro-cyclical manner to economic fluctuations. However, the magnitude of the impact is unclear, as only few studies discuss the effect size. Westergaard-Nielsen and Rue Rasmussen (1999) and Müller and Schweri (2012), for instance, report only a relatively small impact of business cycles.

Askilden and Nilsen (2005) find a pro-cyclical effect of the business cycle on apprentices in Norway, using the unemployment rate as proxy. Furthermore, they test explicitly whether firms with investment- or productionoriented strategies are affected by fluctuations and find evidence for the latter.

Muehlemann et al. (2009) confirm a significant, but small pro-cyclical relationship using panel data of Swiss cantons from 1988 to 2004 . They estimate that a $1 \%$ point decrease of unemployment relates to $0.6 \%$ more apprenticeships. A much stronger reaction appears in relation to demographic fluctuations: a standard deviation change of school graduates is associated with $32 \%$ of new apprenticeships.
In a more recent study, Baldi, Brüggemann-Borck, and Schlaak (2014) examine the short-run relationship between business cycles and the number of apprentices in Germany between 1999 and 2012 and find no robust relationship for both the unemployment rate and (lagged) GDP, except for small effects in West Germany, and only for the period after 2007. Hence, they conclude that 'the apprenticeship system seems to have dampened the volatility of youth unemployment in Germany'.

In addition to analysing panel data, a number of studies also use cross-sectional or survey data of individuals or firms. Weßling, Hartung, and Hillmert (2015) use a German household survey and find that a $1 \%$ point increase of the unemployment rate in the district of residence and in neighbouring districts reduces the trainee's probability of entering an apprenticeship by roughly $1 \%$. Using the IAB firm-level survey, Bellmann, Gerner, and Leber (2016) report that in 2009, German firms decreased the incidence of apprenticeship training by $1.5 \%$ (those affected by the crisis) or $0.21 \%$ (unaffected firms), compared to 2008.

In sum, the empirical literature points to a pro-cyclical reaction in the number of apprenticeships to economic cycles, but most studies report rather small effect sizes.

\section{Institutional background and empirical strategy}

Switzerland provides an ideal environment for examining the effect of business cycles on apprenticeship training for at least 2 reasons. First, the federal structure of the country allows applying a panel data analysis. The country consists of 26 states (cantons), each with its own government and parliament. Although cantons vary in respect to economic and demographic characteristics, the apprenticeship training system is regulated at the national level, ensuring the comparability of the regulatory framework for apprenticeships across all cantons.

Second, vocational education and training (VET) is quantitatively the backbone of Swiss upper-secondary education and not just a niche offered in the education system. Almost two thirds of graduates from compulsory schooling opt for VET, and less than 30\% opt for general education (BFS, 2016). Successful graduates from VET receive a nation-wide recognised diploma, which not only certifies their work-related skills but also entithes them to further education in professional schools or colleges. Only about $10 \%$ of the VET programmes are fully school-based, and the rest of the students opt for apprenticeships that combine work-based learning with school-based education (therefore also called dual education). The apprentice signs a binding, temporary (either 3 or 4 years) valid contract offered by a (private) firm for 1 of the over 200 different training occupations. The firm provides on-the-job training during 3 to 4 days of 
the week, so that the apprentice receives an occupationspecific training programme. For the rest of the time, the apprentice attends one of the vocational schools where he/she receives further vocational and general training.

The 'dual' approach to workplace training and schoolbased training implies that the public (i.e. government and cantons), and the firms share the costs for education and training. While the training in some occupations leaves firms with net costs after training, most firms in Switzerland break even or have a net benefit at the end of the training period, when apprentices are free to leave the firm (Muehlemann \& Wolter, 2014). The net benefit arises because the productive contribution of apprentices during the training period exceeds the costs, which are mainly the apprentice's pay and the expenses for trainers. Previous research has shown that the expected net costs or the net benefit has an impact on the training decision of firms (Muehlemann, Schweri, Winkelmann, \& Wolter, 2007). Therefore, one would expect that factors that have an impact on the potential productive contribution of apprentices should also affect the number of apprenticeships.

\subsection{Data}

We test the empirical relationship between the number of new apprenticeships and the business cycle, using the cantonal unemployment rate $^{1}$ and the cantonal income changes (GDP per capita growth rate) as measures for the business cycle. We estimate linear regressions using a panel dataset for all Swiss cantons from 1987 to 2016. Unfortunately, the data distinguishing between supply and demand of new apprenticeships have never been collected and are not available. We therefore have to rely on the number of newly created apprenticeships in a year and a canton, which reflect the resulting equilibrium between demand and supply.

Two main disadvantages emerge from using apprenticeship numbers. First, only concluded apprenticeships contracts appear in the data, whereas apprenticeship offerings which remain vacant as well as school graduates who do not find an apprenticeship position are not observed, albeit they might affect the next year's number of apprenticeships. It is therefore important to keep in mind that our findings only reflect the effects on the number of filled apprenticeship positions. Second, it remains unclear whether the resulting effects arise due to the changing demand or changing supply. We will discuss this issue in Section 3.

In four cantons, the statistical definition of apprenticeships changed during the analysed period, leading to

\footnotetext{
${ }^{1}$ We use the quota of registered unemployed persons, since the unemployment rate according to the ILO definition is not available for the whole period.
}

structural breaks. We correct for those breaks by including dummies for those individual cantons and years. Likewise, the definition of the cantonal GDP (income) changed four times. Therefore, we impute the national GDP growth for the years between changing definitions. To control for demographic effects, we use the numbers of the population aged 16, which is the typical graduation age on compulsory level (as well as the typical starting age for apprenticeships) in Switzerland.

Table 1 provides the descriptive statistics for the variables used. The absolute number of new apprentices varies largely between cantons because of the differences in size of the cantons. Variations over time within cantons are smaller, mainly reflecting the variation of the youth population. Interestingly, the population aged 16 varies less within cantons than the number of apprentices, what might indicate that further factors have an influence on apprenticeship numbers.

\subsection{Econometrics}

\subsubsection{Static equations}

Our question of interest is whether business cycles affect the number of apprenticeships. Hence, we are only interested in whether changes within cantons affect the number of apprenticeships in this canton, and including fixed effects or taking the first difference is thus essential for all models.

Both the number of apprentices and the population of students aged 16 are non-stationary or trend stationary (see Appendix A). In static regressions, this factor potentially leads to a violation of the Gauss-Markov assumption of strict exogeneity (Wooldridge, 2013). For this reason, we prefer using first difference (FD) models, which require a weaker assumption: $E\left[\left(\varepsilon_{i t}-\varepsilon_{i t-1}\right) \mid\left(\mathbf{x}_{i t}-\mathbf{x}_{i t-1}\right)\right]=0$ for a model of the form:

$$
\Delta A_{i, t}=\alpha_{0}+\Delta \mathbf{x}_{i, t}^{\prime} \beta+\varepsilon_{i t}
$$

where $\Delta$ is the first difference operator, $A_{i t}$ is the number of new apprenticeships for each canton and year, $\mathbf{x}_{i t}$ is the matrix of independent variables, and $\varepsilon_{i t}$ is the error term. To avoid a bias due to spatial correlation ${ }^{2}$, we use panelcorrected standard error (PCSE) as proposed by Beck and Katz (1995). Since the cantons differ in size, all coefficients are weighted according to the total population.

Our model relies on the assumption that the dependent variable (the number of apprentices) does not affect the regressors. This assumption might be questioned for the unemployment rate, if unsuccessful applicants end up unemployed. However, unemployed school graduates account only for a minor part of all unemployed adults, especially since most school graduates who cannot find an apprenticeship start an interim solution programme

\footnotetext{
${ }^{2}$ A Pesaran, Fees, and Friedman test strongly rejects the null hypothesis of cross-sectional independence.
} 
Table 1 Descriptive statistics

\begin{tabular}{|c|c|c|c|c|c|c|}
\hline & \multirow[t]{2}{*}{ Mean } & \multicolumn{3}{|l|}{ St.Dev } & \multirow[t]{2}{*}{ Min } & \multirow[t]{2}{*}{ Max } \\
\hline & & Overall & Between & Within & & \\
\hline Apprentices, entrants & 2419 & 2511 & 2534 & 346 & 95 & 11,332 \\
\hline Population aged 16 & 3258 & 3167 & 3213 & 302 & 181 & 13,843 \\
\hline Unemployment rate in per cent & 2.58 & 1.65 & 1.14 & 1.21 & 0.05 & 7.81 \\
\hline GDP per capita growth rate & 1.30 & 4.25 & 0.66 & 4.20 & -26.3 & 40.7 \\
\hline Baccalaureates, entrants & 776 & 808 & 797 & 204 & 24 & 3414 \\
\hline Share baccalaureates & 0.233 & 0.117 & 0.113 & 0.035 & 0.062 & 0.671 \\
\hline
\end{tabular}

(Jaik \& Wolter, 2016) and do not count as unemployed. Therefore, the resulting bias is likely to be very small.

\subsubsection{Dynamic equations}

While FD models are comparable to previous estimations in the literature, the main disadvantage is that the estimation only captures immediate effects. As we are also interested in long-run effects and as a robustness test, we additionally estimate dynamic models in Section 3.2.

Considering that the number of new apprenticeships directly depends on how many pupils graduate from compulsory schools, it is likely that these series have an equilibrium relationship. Indeed, a Westerlund (2007) test suggests that the number of new apprenticeships and the population aged 16 are cointegrated (cf. Appendix A). On the other hand, the unemployment rate as well as the GDP growth rate are clearly stationary (Table 4 in Appendix A). Hence, autoregressive distributed lag (ADL) models are appropriate and $t$ - as well as $F$ distributions can be used for testing (Banerjee, Dolado, Galbraith, \& Hendry, 1993; Enders, 2004, p. 313).

The basic form of an ADL model can be written as:

$$
A_{i, t}=\alpha_{0}+\alpha_{1} A_{i, t-1}+\mathbf{x}_{i, t}^{\prime} \beta_{1}+\mathbf{x}_{i, t-1}^{\prime} \beta_{2}+\beta_{3} c_{i}+\varepsilon_{i t}
$$

where $\alpha_{1}$ is the autoregressive coefficient, $\beta_{1}$ captures the immediate effects shaping the path towards the equilibrium, $\beta_{2}$ is the permanent impact resulting from a deviation of the equilibrium relationship and $c_{i}$ is the cantonal dummies. The model can be reformulated into the mathematically identical error correction (ECM) form:

$$
\Delta A_{i, t}=\alpha_{0}+\alpha_{1}^{*} A_{i, t-1}+\Delta \mathbf{x}_{i, t}^{\prime} \beta_{1}^{*}+\mathbf{x}_{i, t-1}^{\prime} \beta_{2}^{*}+\beta_{3} c_{i}+\varepsilon_{i t}
$$

where $\alpha_{1}^{*}$ captures the speed of the adjustment (Banerjee et al., 1993). The ECM form has the advantage that the permanent effect (long-run multiplier, LRM) can directly be deviated as $L R M=\beta_{2}^{*} /-\alpha_{1}^{*}$, whereas the same effect equals to $\mathrm{LRM}=\left(\beta_{2}+\beta_{1}\right) /\left(1-\alpha_{1}\right)$ when the ADL form is used (cf. De Boef \& Keele, 2008). To obtain the standard errors of the LRM, we use the Bewley transformation (Banerjee et al., 1993).
The ECM model is thus suitable for our data characteristics to capture both short- and long-term effects. Nevertheless, controlling for fixed effects remains necessary; otherwise, the estimates might be biassed by unobserved variables, for instance larger cantons having more apprentices. By including both, fixed effects and the lagged dependent variable (LDV), we risk that the coefficients would be biassed due to a correlation between the LDV and the error term (Nickell, 1981). However, this bias decreases with increasing $T$, and Beck and Katz (1962) show that such an approach is likely to outperform alternative approaches ${ }^{3}$ for panels with more than 20 periods. We will discuss the bias at the end of Section 3.2.

\section{Results}

\subsection{Static models: immediate effects}

We start by regressing the number of new apprenticeships on the population aged 16, the unemployment rate and the GDP growth, all in the first difference (specification 1 in Table 2). The number of new apprenticeships and the population aged 16 are included in logarithmic form, what makes the interpretation easier. In addition, we include two trend variables, one for the period from 1987 to 1991 and another for the period afterwards. Since the beginning of 1992, the number of apprentices has grown in all cantons simultaneously, as $F$ tests reveal.

For the interpretation of the results, it is important to keep in mind that the regressions only capture the effects of changes over time within each canton. On average, a standard deviation within cantons of both the number of apprenticeships and the population aged 16 represent only $14.3 \%$ and $9.3 \%$, respectively, of the corresponding mean. Hence, regularly offered apprenticeships absorb the bulk of students graduating from compulsory school and fluctuations around the mean are rather small.

${ }^{3}$ Methods using instruments, such as the Arellano-Bond estimators, are not feasible for our panel, since due to the large $T$ ( 30 periods), the number of instruments quickly over-identify the model, even if the number of instruments is restricted (Roodman, 2009). Increasing the number of observations is due to the data restrictions not possible. 
Table 2 Static regression table (immediate effects only), 1987-2016

\begin{tabular}{|c|c|c|c|c|c|}
\hline & (1) & (2) & (3) & (4) & (5) \\
\hline \multirow[t]{2}{*}{$\Delta \log (\text { Pop. aged } 16)_{t, t-1}$} & $0.249^{* * *}$ & $0.274^{* * *}$ & $0.266^{* * *}$ & $0.244^{* * *}$ & $0.243^{* * *}$ \\
\hline & $(0.061)$ & $(0.070)$ & $(0.069)$ & $(0.060)$ & $(0.059)$ \\
\hline \multirow[t]{2}{*}{$\Delta$ Unemployed $_{t, t-1}$} & $-1.542^{* * *}$ & & & $-1.486^{* * *}$ & $-1.290^{* * *}$ \\
\hline & $(0.361)$ & & & $(0.350)$ & $(0.397)$ \\
\hline \multirow[t]{2}{*}{$\Delta$ Unemployed $_{t, t-1}^{\Delta>0}$} & & & & & -0.108 \\
\hline & & & & & $(0.107)$ \\
\hline \multirow[t]{2}{*}{$\Delta \mathrm{GDP}$ growth $\mathrm{t}_{t, t-1}$} & & -0.009 & & & \\
\hline & & $(0.054)$ & & & \\
\hline \multirow[t]{2}{*}{$\Delta \mathrm{GDP}$ growth $_{t-1, t-2}$} & & & $0.108^{* *}$ & $0.085^{*}$ & $0.116^{*}$ \\
\hline & & & $(0.052)$ & $(0.044)$ & $(0.066)$ \\
\hline \multirow[t]{2}{*}{$\Delta \mathrm{GDP} \operatorname{growth}_{\mathrm{t}-1, \mathrm{t}-2}^{\Delta<0}$} & & & & & -0.069 \\
\hline & & & & & $(0.114)$ \\
\hline \multirow[t]{2}{*}{$\Delta \operatorname{Trend}_{t, t-1}^{1987-1991}$} & 0.001 & 0.006 & 0.007 & 0.002 & 0.002 \\
\hline & $(0.004)$ & $(0.005)$ & $(0.005)$ & $(0.004)$ & $(0.004)$ \\
\hline \multirow[t]{2}{*}{$\Delta \operatorname{Trend}_{t, t-1}^{1992-2016}$} & $0.033^{* * *}$ & $0.037^{* * *}$ & $0.036^{* * *}$ & $0.033^{* * *}$ & $0.033^{* * *}$ \\
\hline & $(0.009)$ & $(0.011)$ & $(0.011)$ & $(0.009)$ & $(0.008)$ \\
\hline \multirow[t]{2}{*}{ Constant } & $-0.025^{* * *}$ & $-0.029^{* * *}$ & $-0.029^{* * *}$ & $-0.025^{* * *}$ & $-0.025^{* * *}$ \\
\hline & $(0.008)$ & $(0.010)$ & $(0.010)$ & $(0.008)$ & $(0.008)$ \\
\hline Observations & 780 & 780 & 780 & 780 & 780 \\
\hline Number of region & 26 & 26 & 26 & 26 & 26 \\
\hline
\end{tabular}

Dependent variable: $\Delta \log ($ Apprenticeships $t, t-1)$. First difference model with panel-corrected standard errors (PCSE, in brackets). ${ }^{* * *} p<0.01,{ }^{* *} p<0.05,{ }^{*} p<0.1$

The elasticity of new apprenticeship entrants with respect to the population aged 16 is roughly 0.25 (Table 2 ). That is, for $10 \%$ additional adolescents aged 16 , we can expect approximately $2.5 \%$ more apprenticeships the same year. A standard deviation change in the population aged 16 within cantons $(9.3 \%$ at the mean) relates to an immediate change of $2.3 \%$ in the average number of apprenticeships.

Regarding unemployment, the results suggest that changing labour market conditions imply a considerably weaker, yet statistically significant, effect. On average, a $1 \%$ point increase of the unemployment rate relates to approximately $1.5 \%$ fewer apprentices. A standard deviation in the unemployment rate within cantons $(1.21 \%$ points) thus relates-ceteris paribus-to a change in the mean of the number of apprentices of $1.8 \%$. Compared to Muehlemann et al. (2009), our estimation shows a more pronounced effect.

For the second proxy of the business cycle (per capita income growth) in specification 2, there is no immediate effect observable. If the previous year's GDP growth rate is included instead as in specification 3 , the positive coefficient suggests a pro-cyclical effect. A $1 \%$ point increase in the income growth rate translates into $0.1 \%$ additional new apprenticeships. If both variables, unemployment and income, are included into the same estimation (specification 4), the effects are weaker, and the $p$ value for the GDP growth coefficient is with 0.053 only significant at the $10 \%$ level. This might reflect that changes in GDP and the unemployment rate occur partly simultaneous, although the correlation coefficient $(-0.08)$ suggests no relationship.

In specification 4, we test the hypothesis on whether the firms react to booms and recessions in an asymmetric way: To test this possibility, we used two additional variables: $\Delta$ Unemployed $_{t, t-1}^{\Delta>0}$, which is 0 in periods when the unemployment rates declined and equals $\Delta$ Unemployed $_{t, t-1}$ if the rates increased, and $\Delta$ GDP growth $\mathrm{t}_{\mathrm{t}-1, \mathrm{t}-2}^{\Delta<0}$, with only the observations during recessions. The result suggests that the response to rising unemployment numbers is slightly stronger, but the differences in the responses are not significant.

As the data do not distinguish between demand and supply, it is unclear which of both affects the apprenticeship numbers. The demand for apprenticeships is driven by two factors: the size of the school-leaving cohort 
and their preferences. While we control for population aged 16, it is possible that business cycles affect the preferences, i.e. alter the perceived opportunities of general education compared to vocational education (Glauser \& Becker, 2016). In this case, we would expect that business cycles affect the number of new baccalaureate students. In Appendix A, we test this hypothesis, but we do not find any significant effects, in line with Muehlemann et al. (2009). Hence, post-compulsory attainment appears mainly to be affected by the individual competences and other factors (Zumbühl \& Wolter, 2017), but not by economic fluctuations, and we interpret the business-cycle effects found in this paper as supply-driven.

\subsection{Dynamic models}

The inter-temporal ambiguity of potential business cycle effects (cf. chapter 1) motivates the analysis of dynamics between the business cycle and apprenticeships. As mentioned in Section 2.2, we estimated ADL models in EC form with one lag. ${ }^{4}$ Since all independent variables are either co-integrated (population aged 16) or stationary (GDP growth and unemployment rate), the error terms are stationary (cf. Appendix A.1). Table 3 shows the results.

In specification 1, we examine the short- and longrun effects of the unemployment rate and the population aged 16. For the latter, the immediate effect (within the same year) is similar to the stationary coefficient: For an additional per cent school graduates aged 16, firms hire $0.25 \%$ more apprentices during the year. Furthermore, the variable has a positive, highly significant coefficient in the subsequent year, resulting in a long-term effect of $0.280 /-(-0.422)=0.664$. This reflects the fact that, although the majority of school graduates start an apprenticeship immediately, a fraction does so only after an interim year (see e.g. Jaik \& Wolter, 2016) or being older than 16. This demographic effect remains similar in all three specifications.

The immediate effect of the unemployment rate suggests that firms respond to a $1 \%$ point increased unemployment rate by hiring $1.8 \%$ fewer apprentices during the same year, a slightly stronger response as estimated in the static models. This confirms that the fluctuations on the labour market have a pro-cyclical immediate effect on vocational training. However, the very small permanent coefficient of the unemployment rate suggests that, in the subsequent year, the response reverses. The total longterm effect is estimated by LRM $=-0.313 /-(-0.422)=$ -0.743 , and is statistically significantly different from

\footnotetext{
${ }^{4}$ We also tested further lags for dependent and independent variables. Yet, since the $F$ test that all the corresponding coefficients equal to 0 cannot be rejected, we report only one lag.
}

Table 3 Dynamic regression table, 1987-2016

\begin{tabular}{|c|c|c|c|}
\hline & (1) & $(2)$ & (3) \\
\hline \multirow[t]{2}{*}{$\log (\text { Apprenticeships })_{t-1}$} & $-0.422^{* * *}$ & $-0.392^{* * *}$ & $-0.418^{* * *}$ \\
\hline & $(0.040)$ & $(0.041)$ & $(0.040)$ \\
\hline \multicolumn{4}{|l|}{ Immediate, transitory effects } \\
\hline \multirow[t]{2}{*}{$\Delta \log (\text { Population aged } 16)_{t, t-1}$} & $0.247^{* * *}$ & $0.259^{* * *}$ & $0.239^{* * *}$ \\
\hline & $(0.058)$ & $(0.065)$ & $(0.057)$ \\
\hline \multirow[t]{2}{*}{$\Delta$ Unemployed $_{t, t-1}$} & $-1.765^{* * *}$ & & $-1.595^{* * *}$ \\
\hline & $(0.332)$ & & $(0.339)$ \\
\hline \multirow[t]{2}{*}{$\Delta \mathrm{GDP}$ growth $\mathrm{g}_{t, t-1}$} & & 0.109 & 0.054 \\
\hline & & $(0.068)$ & $(0.058)$ \\
\hline \multicolumn{4}{|l|}{ Permanent effects } \\
\hline \multirow[t]{2}{*}{$\log (\text { Population aged } 16)_{t-1}$} & $0.280^{* * *}$ & $0.262^{* * *}$ & $0.264^{* * *}$ \\
\hline & $(0.042)$ & $(0.045)$ & $(0.042)$ \\
\hline \multirow[t]{2}{*}{ Unemployed $_{t-1}$} & -0.313 & & -0.285 \\
\hline & $(0.239)$ & & $(0.237)$ \\
\hline \multirow[t]{2}{*}{ 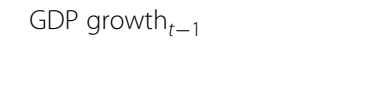 } & & $0.285^{* * *}$ & $0.141^{*}$ \\
\hline & & $(0.095)$ & $(0.082)$ \\
\hline \multirow[t]{2}{*}{ Trend ${ }^{1987-1991}$} & $-0.006^{*}$ & -0.002 & -0.005 \\
\hline & $(0.003)$ & $(0.004)$ & $(0.003)$ \\
\hline \multirow[t]{2}{*}{ Trend ${ }^{1992-2015}$} & $0.003^{* * *}$ & $0.003^{* * *}$ & $0.003^{* * *}$ \\
\hline & $(0.000)$ & $(0.001)$ & $(0.000)$ \\
\hline Observations & 780 & 780 & 780 \\
\hline Number of region & 26 & 26 & 26 \\
\hline Regional fixed effects & Yes & Yes & Yes \\
\hline
\end{tabular}

Dependent variable: $\Delta \log \left(\right.$ Apprenticeships $\left._{t, t-1}\right)$. ADL model in EC form, with panel-corrected standard errors (PCSE, in brackets). ${ }^{* *} p<0.01,{ }^{* *} p<0.05,{ }^{*} p<0.1$

zero. ${ }^{5}$ Hence, a 1 percentage point increased unemployment rate eventually relates to only $0.7 \%$ fewer apprenticeships. The long-term effect is thus considerably weaker than the immediate response, implying that some firms hire more apprentices than usual in subsequent year.

In specification 2, we include the GDP per capita growth rate instead of the unemployment rate. The short-run coefficient is pro-cyclical, but statistically not significant. The permanent effect, given by $0.285 /-(-0.392)=$ 0.727 , is stronger, indicating that the pro-cyclical response continues in subsequent years. Considering the LRM standard error of 0.098, the long-term effect is statistically different from zero with a $p$ value of 0.000 .

The final ${ }^{6}$ specification 3 includes both proxies, unemployement and GDP, in one equation. All effects, including

${ }^{5}$ The standard errors of permanent effects are estimated by applying the Bewley transformation (cf. De Boef \& Keele, 2008).

${ }^{6}$ Again, we also estimated asymmetric effects, i.e. whether the response differs during booming periods and recessions. However, as all coefficients including permanent effects are insignificant, no asymmetric responses are observable. 
permanent responses, are slightly weaker but similar, indicating a covariance of the variables. A substantial difference results for the permanent effect of a changing GDP growth: The long-term impact decreases to 0.337 in specification 3, but remains with a standard error of 0.084 highly significant.

To illustrate the dynamics, we plotted the impulse response function (IRF, effect of one-time shock of the independent variable at $t=0$ ) and the total, cumulative effect for a one unit change in Fig. 2. The total effects converge towards the long-run multiplier.

The results indicate that a changing unemployment rate induces an pro-cyclical response by the number of filled apprenticeship positions during the same year. In the following year, the response reverses, leading to a weaker permanent effect. In contrast, the procyclical response on a GDP growth shock is stronger in the second year after the shock. As a consequence, the permanent effect increases slightly over the time, if we ignore subsequent GDP changes. These dynamics explain why only a lagged GDP growth rate results with a significant coefficient in the static regressions.
Overall, demographic changes explain a larger part of the apprenticeship fluctuations than the business cycle, while most apprenticeship positions are filled on a regular basis, regardless of demographic and economic fluctuations.

As mentioned in Section 2.2, these results are biassed by a covariance between the lagged dependent variable (LDV) and the time-invariant cantonal variables. Yet, due to the long sample with 30 periods, this bias is small for our panel. Applying Nickell's (1981) approximation of the LDV bias, $\operatorname{plim}_{n \rightarrow \infty}(\hat{\rho}-\rho) \simeq \frac{-(1+\rho)}{T-1}$, the bias equals to about -0.055 for $\rho=-0.4$. Hence, the real LDV coefficient might be about $13 \%$ smaller, and the persistence of the effects would be underestimated. This would, however, neither qualitatively nor quantitatively change much of our findings.

\section{Conclusions}

Our analysis suggests the provision of apprenticeships in countries with well-established and quantitatively important apprenticeship training systems does react to business cycles, but the effects are moderate. Most firms,
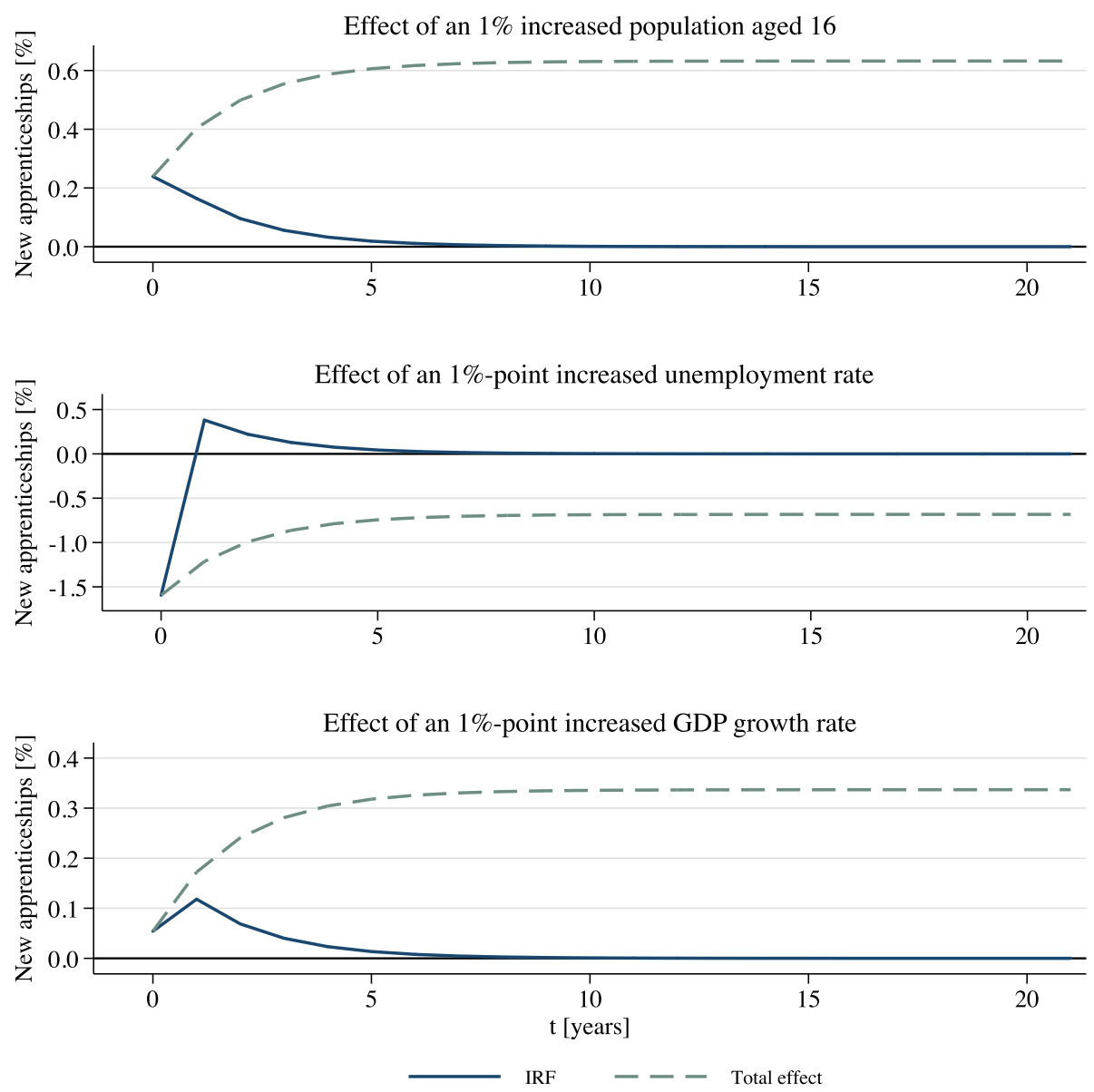

Fig. 2 Dynamic effects of the population aged 16, unemployment rates and GDP per capita in specification 3 
once having decided to be active in apprenticeship training, offer positions on a regular basis (Muehlemann et al., 2007); hence, fluctuations in the number of apprenticeships are small.

Within existing fluctuations, however, we find a moderate, pro-cyclical effect of business cycles, suggesting that some firms do adjust their training strategy to the economic climate or that the number of firms that cease to exist in a recession is not substituted by more training activities of the remaining firms (and vice versa) in the short run. A change in the unemployment rate is associated with an immediate response in the number of apprenticeships. This effect, however, is only transitory and is reversed in the following year. Our interpretation of this finding is that a number of firms only postpone (or advance) their initial training decisions. That is, in the case of a tightening labour market, where the unemployment rate falls, some firms hire additional apprentices, for instance, if they cannot find suitable skilled workers. In turn, some of those firms forgo offering the same apprenticeship position in the following year. Conversely, some firms might delay their planned hires in the situation of a loosening labour market. Such a behaviour can be interpreted as evidence for a substitution effect between apprentices and skilled workers for firms pursuing a production-oriented training strategy, in line with the findings by Askilden and Nilsen (2005). Such firms, however, appear to adjust their training behaviour only temporarily to changing labour market conditions, before returning to their previous, optimal training efforts.

A change in the GDP per capita, on the other hand, induces a permanent change in the number of filled apprenticeship positions, suggesting that structural output shocks affect apprenticeship investment decisions permanently. This behaviour is in line with the hypothesis that training investments depend on the expected future production: Firms which hire apprentices mainly as investment for their future production adjust their training strategy in case of changing expectations due to persisting shocks. However, the magnitude of this effect is moderate, what might due to the fact that only about a third of the training firms in Switzerland train apprentices with the purpose of covering their future demand of skilled workers. The crisis after 2008, for instance, caused a decrease of the Swiss GDP by $3.1 \%$, which in turn relates to about $1 \%$ of fewer apprenticeship positions in the long run, if subsequent GDP changes are ignored. Overall, the results suggest that both, firms pursuing an investment- and those pursuing a production-oriented strategy, are affected by business cycles.

From a policy perspective, the youth's situation in the apprenticeship training market thus depends mainly on dynamics between demographic fluctuations and economic cycles. In years of smaller school-leaving cohorts, the offers for apprenticeships from the firms do not fall proportionally, making it easier for students graduating from compulsory school to find a position. This helped the youths in the economically difficult period between 2008 and 2014, when the population aged 16 decreased on average by $1 \%$ yearly. On the other hand, the impact of an economically difficult environment would affect the apprenticeship market much stronger if the recession would coincide with years of expanding cohorts of school leavers.

Our empirical findings, however, are limited to advanced VET systems, where apprenticeships are offered across almost all economic sectors and cover a wide range of occupations. This diversity increases the robustness in case of downturns, which usually affects industries to a varying degree. In countries where apprenticeships are concentrated in particular industries and occupations, the overall impact of economic cycles on the provision of apprenticeships might therefore be much stronger.

\section{Appendix A. Econometric tests}

\section{A.1 Unit root tests}

Table 4 Levin-Lin-Chu unit root test. $H_{0}$ : panels contain unit roots

\begin{tabular}{llllll}
\hline Variable & \multicolumn{3}{c}{ Without trend } & & \multicolumn{2}{c}{ With trend } \\
\cline { 2 - 3 } & Adjusted $t$ & $p$ value & & Adjusted $t$ & $p$ value \\
\hline log(Apprenticeships) & 0.045 & 0.058 & & -4.272 & 0.000 \\
log (Population aged 16) & -0.613 & 0.270 & & 0.950 & 0.829 \\
Unemployment rate & -13.940 & 0.000 & & -11.999 & 0.000 \\
GDP growth rate & -18.625 & 0.000 & & -16.787 & 0.000
\end{tabular}

Error terms of dynamic regressions

$\begin{array}{lll}\text { Specification 1 } & -20.173 & 0.000 \\ \text { Specification 2 } & -23.412 & 0.000 \\ \text { Specification 3 } & -22.494 & 0.000\end{array}$

Specification $3 \quad-22.494 \quad 0.000$

\section{A.2 Cointegration}

Westerlund ECM panel cointegration test on apprentices and the population aged 16 with constant and trend:

Table 5 Westerlund cointegration test. $H_{0}$ : no cointegration

\begin{tabular}{lllll}
\hline & & Statistic & $z$ value & $p$ value \\
\hline Group mean test & $G_{\tau}$ & -3.247 & -5.523 & 0.000 \\
& $G_{\alpha}$ & -15.877 & -2.899 & 0.002 \\
\multirow{3}{*}{ Whole panel } & $P_{\tau}$ & -14.566 & -4.339 & 0.000 \\
& $P_{\alpha}$ & -13.718 & -3.980 & 0.000 \\
\hline
\end{tabular}




\section{Appendix B. Baccalaureates}

In Table 6, we regress the business cycle indicators on the number of baccalaureate entrants (specifications 1 and 2 ) and the share of baccalaureate entrants amongst the population aged 16 (specification 3). Neither the unemployment rate nor the GDP per capita affects the number of new baccalaureate students. A growing cohort of 16year-old graduates increases the number of baccalaureate students, but such demographic fluctuations have a larger effect on the number of apprenticeships, which is why the share of baccalaureate students decreases slightly.

Table 6 Static regression table on baccalaureate entries, 1987-2016

\begin{tabular}{llll}
\hline & $(1)$ & $(2)$ & $(3)$ \\
\hline$\Delta \log \left(\right.$ Population aged 16) $_{t, t-1}$ & $0.285^{* *}$ & $0.284^{* *}$ & $-0.164^{* * *}$ \\
& $(0.120)$ & $(0.117)$ & $(0.030)$ \\
$\Delta$ Unemployed $_{t, t-1}$ & 0.334 & 0.809 & 0.119 \\
& $(0.565)$ & $(0.621)$ & $(0.136)$ \\
$\Delta$ Unemployed $_{t, t-1}^{\Delta>0}$ & & -0.271 & \\
& & $(0.178)$ & \\
$\Delta$ GDP growth $_{t, t-1}$ & 0.062 & -0.017 & 0.016 \\
& $(0.076)$ & $(0.123)$ & $(0.023)$ \\
$\Delta$ GDP growth $^{\Delta<0} t, t-1$ & & 0.132 & \\
Constant & & $(0.215)$ & \\
& $0.016^{* * *}$ & $0.016^{* * *}$ & $0.003^{* * *}$ \\
Observations & $(0.005)$ & $(0.004)$ & $(0.001)$ \\
Number of region & & & \\
\hline
\end{tabular}

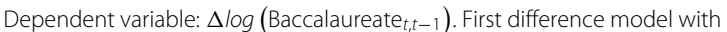
panel-corrected standard errors (PCSE, in brackets). ${ }^{* * *} p<0.01,{ }^{* *} p<0.05,{ }^{*} p<0.1$

\section{Abbreviations}

ADL: Autoregressive distributed lag; BFS: Federal Statistical Office (Bundesamt für Statistik); ECM: Error correction model; FD: First difference; GDP: Gross domestic product; IAB: Institut für Arbeitsmarkt- und Berufsforschung; LDV: Lagged dependent variable; LRM: Long-run multiplier; OECD: Organisation for Economic Co-operation and Development; PCSE: Panel-corrected standard error; VET: Vocational education and training
\end{abstract}

\section{Acknowledgements}

We would like to thank Maria Zumbuehl, Aurélien Abrassart, Katharina Jaik and Andreas Bachmann as well as the editor and two anonymous reviewers for their very helpful suggestions which led to a considerable improvement of the analysis in our paper.

\section{Authors' contributions}

SW designed and supervised the study. SL analysed the data. Both authors drafted the article and approved the final manuscript.

\section{Funding}

This research was co-funded by the Leading House on the Economics of Education, a research initiative of the Swiss State Secretariat for Education, Research and Innovation.

\section{Availability of data and materials}

The datasets used and analysed during the current study are based on FSO data (https://www.bfs.admin.ch/bfs/en/home.html) and are available from the corresponding author on reasonable request.

\section{Competing interests}

The authors declare that they have no competing interests.

\section{Author details}

${ }^{1}$ Centre for Research in Economics of Education, University of Bern, Bern, Switzerland. ${ }^{2}$ Swiss Coordination Centre for Research in Economics of Education, Aarau, Switzerland.

Received: 13 February 2019 Accepted: 16 September 2019

Published online: 04 February 2020

\section{References}

Askilden, J.E, \& Nilsen Ø.A (2005). Apprentices and young workers: a study of the Norwegian youth labour market. Scottish Journal of Political Economy, 52(1), 1-17. https://doi.org/10.1111/j.0036-9292.2005.00331.x.

Baldi, G, Brüggemann-Borck, I, Schlaak, T (2014). The effect of the business cycle on apprenticeship training: evidence from Germany. Journal of Labor Research, 35(4), 412-422

Banerjee, A., Dolado, J.J., Galbraith, J.W., Hendry, D. (1993). Cointegration, error correction, and the econometric analysis of nonstationary data. New York: Oxford University Press.

Beck, N., \& Katz, J.N. (1995). What to do (and not to do) with time-series cross-section data. American Political Science Review, 89(03), 634-647.

Beck, N., \& Katz, J.N. (1996). Nuisance vs. substance: specifying and estimating time-series-cross-section models. Political Analysis, 6, 1-36.

Becker, G.S. (1962). Investment in human capital: a theoretical analysis. Journal of political economy, 70(5), 9-49.

Bellmann, L., Gerner, H.-D., Leber, U. (2016). Firm-provided training during the great recession. Jahrbücher für Nationalökonomie und Statistik, 234(1), 5-22.

BFS (2016). Der Übergang am Ende der obligatorischen Schule: Ausgabe 2016. (Tech. Rep. No. 1665-1600). Neuchâtel: Bundesamt für Statistik (BFS)

Brunello, G. (2009). The effect of economic downturns on apprenticeships and initial workplace training: a review of the evidence. (IZA Discussion Papers No. 4326). Institute for the Study of Labor (IZA).

De Boef, S., \& Keele, L. (2008). Taking time seriously. American Journal of Political Science, 52(1), 184-200.

Enders, W. (2004). Applied econometric time series. New York: Wiley.

Glauser, D., \& Becker, R. (2016). VET or general education? Effects of regional opportunity structures on educational attainment in German-speaking Switzerland. Empirical Research in Vocational Education and Training, 8, 8.

Heyes, J. (2013). Vocational training, employability and the post-2008 jobs crisis: responses in the European Union. Economic and Industrial Democracy, 34(2), 291-311.

Jaik, K., \& Wolter, S.C. (2016). Lost in Transition: The Influence of Locus of Control on Delaying Educational Decisions. IZA Discussion Papers, 10191.

Lindley, R.M. (1975). The demand for apprentice recruits by the engineering industry: 1951-1971. Scottish Journal of Political Economy, 22(1), 1-24.

Merrilees, W.J. (1983). Alternative models of apprentice recruitment: with special reference to the british engineering industry. Applied Economics, 15(1), 1-21.

Muehlemann, S., Schweri, J., Winkelmann, R., Wolter, S.C. (2007). An empirical analysis of the decision to train apprentices. LABOUR, 21(3), 419-441.

Muehlemann, S., \& Strupler Leiser, M. (2018). Hiring costs and labor market tightness. Labour Economics, 52, 122-131.

Muehlemann, S., \& Wolter, S.C. (2014). Return on investment of apprenticeship systems for enterprises: evidence from cost-benefit analyses. IZA Journal of Labor Policy, 3, 25.

Muehlemann, S, Wolter, S.C, Wueest, A (2009). Apprenticeship training and the business cycle. Empirical research in vocational education and training, 1(2), $173-186$. 
Müller, B., \& Schweri, J. (2012). Die Betriebe in der dualen Berufsbildung: Entwicklungen 1985 bis 2008 (Tech. Rep. No. 977-1200-05). Neuchâtel: Bundesamt für Statistik.

Nickell, S. (1981). Biases in dynamic models with fixed effects. Econometrica, 49(6), 1417-1426.

OECD (2010). Learning for jobs. Paris: OECD Publishing.

Quintini, G., \& Manfredi, T. (2009). Going separate ways? School-to-work transitions in the United States and Europe (OECD Social, Employment and Migration Working Paper No. 90). Paris: OECD Publishing.

Roodman, D. (2009). A note on the theme of too many instruments. Oxford Bulletin of Economics and Statistics, 71(1), 135-158.

Scarpetta, S., Manfredi, T., Sonnet, A. (2010). Rising youth unemployment during the crisis (OECD Social, Employment and Migration Working Papers No. 106).

Steedman, H. (2014). Overview of apprenticeship systems and issues (Tech. Rep.) Geneva: ILO

Weßling, K., Hartung, A., Hillmert, S. (2015). Spatial structure counts: the relevance of regional labour-market conditions for educational transitions to vocational training. Empirical Research in Vocational Education and Training, 7(1), 12.

Westergaard-Nielsen, N., \& Rue Rasmussen, A. (1999). The impact of subsidies on apprenticeship training (Tech. Rep.) Aarhus: Centre for Labour Market and Social Research.

Westerlund, J. (2007). Testing for error correction in panel data. Oxford Bulletin of Economics and statistics, 69, 709-748.

Wolter, S.C., \& Ryan, P. (2011). Apprenticeship. In E. Hanushek, S. Machin, L. Woessmann (Eds.), Handbook of Economics of Education, Vol. 3 (pp. 521-576). Amsterdam: Elsevier.

Wooldridge, J.M. (2013). Introductory econometrics: a modern approach, 5th ed. Mason: South-Western Cengage Learning.

Zumbühl, M., \& Wolter, S.C. (2017). Wie weiter nach der obligatorischen Schule? Bildungsentscheidungen und-verläufe der PISA-Kohorte 2012 in der schweiz. SKBF Staff Paper 20.

\section{Publisher's Note}

Springer Nature remains neutral with regard to jurisdictional claims in published maps and institutional affiliations.

\section{Submit your manuscript to a SpringerOpen ${ }^{\circ}$ journal and benefit from:}

- Convenient online submission

- Rigorous peer review

- Open access: articles freely available online

- High visibility within the field

- Retaining the copyright to your article

Submit your next manuscript at $\gg$ springeropen.com 